\title{
Impact of hiking trails on the diversity of flower-visiting insects in Wadi Telah, St. Katherine protectorate, Egypt
}

\author{
Mohamed Kamel[D
}

\begin{abstract}
Background: A hiking trail is one of the major recreational activities that have critical impacts on wildlife. Wadi Telah in Saint Katherine Protectorate (South Sinai, Egypt) (N 28.568539 and E 33.932816) is an important spot for biodiversity. It was surveyed for spatial variation in the diversity of flower-visiting insects at different distances from the hiking trail. The current study aimed at assessing the impact of some anthropogenic activities along the main hiking trail passing through $\mathrm{W}$. Telah on the diversity of flower-visiting insects. Field monitoring of flower visitors across the hiking trail passing through $\mathrm{W}$. Telah was carried out at different distances $(\sim 0,20,40$, and $60 \mathrm{~m})$ along both sides of the hiking trail. As a control, monitoring was performed at $120 \mathrm{~m}$ from the hiking trail.

Results: A total of 542 individuals belonging to 34 species of flower visitors, 16 families, from three orders were recorded within the study localities in W. Telah. Floral resources in Wadi Telah can be a limiting factor for the populations of flower visitors. There was a significant difference in the distribution of the flower visitors' species richness among different distances from the hiking trail in W. Telah. Species richness and abundance of flower visitors and their associated floral resources were significantly positively correlated to the distance from the hiking trail. There were no significant differences in the diversity of flower-visiting insects among different distances from the trail, perhaps due to their mobility.

Conclusions: The present study showed that the hiking trail had a negative impact on flower visitors and their associated floral resources in Wadi Telah. The investigation on how different biodiversity elements respond to hiking trails allows greater insight for protectorate managers. The study can contribute to effective management decisions for current and future protectorates.
\end{abstract}

Keywords: Biodiversity, Flower-visiting insects, Anthropogenic activities, Hiking trails, Sinai

\section{Introduction}

St. Katherine Protectorate (SKP) is a distinctive area for biological diversity with high scientific and economic value. It includes the highest mountains in Egypt, which uphold special ecosystems, with a distinctive faunal and floral diversity (Baha El Din, 2006) and a relatively high occurrence of endemic species (SKP-M.P, 2003).

Wadi Telah (1370-1608 m a.s.l.) (N 28.568539 and E 33.932816) is one of the most important biodiversity rich

Correspondence: Mohamed.kamel@iesr.asu.edu.eg

Department of Environmental Basic Sciences, Institute of Environmental

Studies and Research, Ain Shams University, Cairo, Egypt spots in SKP area. A major hiking trail about $4 \mathrm{~km}$ long and about $(1-2 \mathrm{~m})$ wide pass through the rich spots in W. Telah and is used by local Bedouins and tourists during their visits to the area. It is an informal trail created by the trampling actions of the visitors.

Protected areas permit a separation of the direct effect of anthropogenic activities on biodiversity from those of other environmental variables (Sinclair, Mduma, \& Arcese, 2002). Accordingly, the protected area presents ideal systems for evaluating the impact of human activities (Souza \& Prevedello, 2020). Protected areas are substantial for long-term conservation of overexploited plants. Also, 
the frequency and density of native species are higher inside protected areas (Souza \& Prevedello, 2020). Also, protected areas are generally efficient at preserving habitats for species and thus saving suitable conditions for the occurrence and maintenance of many species (Geldmann et al., 2013). SKP faces several threats to its conservation status (Fouda et al., 2006). The protectorate faces some global threats such as climate change and tourism, while others arise from local necessities and socioeconomic issues (e.g., the overharvesting of wild plants) (Grainger \& Gilbert, 2008).

Nature-based tourism and recreation activities such as hiking, the viewing of wildlife, and cycling close to or within protected areas might have negative impacts on animal populations and biodiversity within protected areas (Huhta \& Sulkava, 2014). There are apparent direct impacts of recreation activities such as damage from trampling or clearing of vegetation for infrastructure (Pickering \& Hill, 2007). The impacts on fauna, flora, soil, and water resources are generally most obvious at areas subjected to massive visitor numbers especially hiking trails and campsites (Tomczyk, 2011). A hiking trail is a critical recreational activity that has serious impacts on ecosystems (Queiroz, Ventura, \& Silva, 2014). Hiking trail may displace animals from otherwise suitable habitat; also, animals may change their activity patterns according to interactions with recreationists (Reilly, Tobler, Sonderegger, \& Beier, 2017). The human disturbance had a great effect on the animal foraging percentage in the daytime activity budget, which increased as the day proceed and at greater distances from the closest hiking trail (Pęksa \& Ciach, 2018).

Many insects visit plant flowers, to obtain pollen, nectar, or feed on other flower parts. Many of these interactions result in pollination. Globally, several studies on the flower-visiting insects, especially insect pollinators are endangered and in decline over the world (Winfree, Bartomeus, \& Cariveau, 2011). The diversity and abundance of pollinators are negatively affected by several stresses like climate change, habitat destruction, fragmentation, and the unavailability of floral resources (Shakeel et al., 2019). Insect pollinators have mutual relationships with flowering plants to gain nectar and pollen (Arenas \& Farina, 2012). Decreased pollinators' diversity and abundance may lead to a decline in plant species diversity (Biesmeijer et al., 2006). Pollinators provide several ecological services including the following: maintain a healthy ecosystem, increase the genetic diversity of plants, secure plant reproduction, and increase the plant yields, such as the number of pods, seeds, seed weights per plant, and seed germination (Siregar, Atmowidi, \& Kahono, 2016).

Insect pollinators as are effective bioindicators that can be used to monitor several environmental impacts performed by biological factors such as diseases, parasites, introduced competitors, and predators as well as by physical and chemical factors, particularly habitat modification and pesticides (Kevan, 1999; Siddig, Ellison, Ochs, Villar-Leeman, \& Lau, 2016). Habitat modification and fragmentation brought by human activities are key drivers of change to plant-pollination interactions (Stout, 2014; Winfree, Aguilar, Vázquez, Lebuhn, \& Aizen, 2009). Recent evidence indicated that diversity and abundance of highly mobile pollinator species can be affected by the landscape assembly and configuration around the site in which they are being monitored (Kennedy et al., 2013; Stout, 2014).

Several insect groups are known as pollinators of various plants. Butterflies, bees, moths, beetles, wasps, and flies are documented as plant pollinators (Siregar et al., 2016). Few studies recognized the insect-pant pollination system in the high mountainous area of SKP (Gilbert, Willmer, Semida, Ghazoul, \& Zalat, 1996; Norfolk \& Dathe, 2019; Norfolk, Eichhorn, \& Gilbert, 2014a; Semida, 2000). Over 40 butterfly species have been reported within SKP (Gilbert \& Zalat, 2008). The butterflies' abundance, species richness, and diversity decrease in response to increasing anthropogenic utilization (Jew, Loos, Dougill, Sallu, \& Benton, 2015). Bees provide principal ecological services and contribute to the survival of plant species and the conservation of biodiversity (Shebl, Patiny, \& Michez, 2015). Many studies reported the faunal diversity and composition of bees in Egypt and their role in plant pollination, especially the solitary bees (Norfolk et al., 2014a; Norfolk \& Dathe, 2019; Semida, 2000; Shebl \& Farag, 2015; Shebl, Kamel, \& Mahfouz, 2013). Sixty-two species of bees were recorded at the Canal region (Shebl et al., 2013; Shebl et al., 2015; Shebl \& Farag, 2015). Furthermore, two new species of solitary bees were identified and collected from Sinai (Badawy, 2003). Also, several flower visitors were collected, identified, and added to the Egyptian pollinator checklist from South Sinai. One hundred twelve species of flower visitors belonging to five insect orders (Coleoptera, Diptera, Hemiptera, Hymenoptera, and Lepidoptera) were recorded in SKP (Norfolk \& Dathe, 2019). The Hymenoptera were the most diverse group of flower visitors, consisting of 69 species from eight families: Apidae, Colletidae, Crabronidae, Halictidae, Megachilidae, Scoliidae, Sphecidae, and Vespidae (Norfolk \& Dathe, 2019).

Recent evidence showed that the impact of the hiking trail is less harmful than a road impact, but even a narrow hiking trail could fragment the habitat of small invertebrates (Mader, 1984). Also, several types of research assessed local-scale impacts of trails by comparing effects at increasing distances from a trail and against undisturbed conditions. Species richness is used to assess the anthropogenic impact such as habitat changes on biodiversity (Barragan, Moreno, Escobar, Halffter, \& Navarrete, 2011; Michelsen, McDevitt, \& Coelho, 2014). 
Accordingly, the present study is designed for identifying and quantifying of flower visitors' species within Wadi Telah. The study is also aimed at assessing the impact of the hiking trail passing through Wadi Telah on the diversity of flower-visiting insects.

\section{Materials and methods}

\section{Study area}

St. Katherine Protectorate extends over the entire mountain massif of South Sinai with an area of $4350 \mathrm{~km}^{2}$ (Fig. 1) and it is characterized by the highest elevations in Egypt and a dense Wadi system (SKP-M.P, 2003). SKP is the coolest area in Sinai due to its high elevation (1500-2641 m above sea level). It was declared as a protected area in 1996 due to its biological and cultural significance (SKP-M.P, 2003). SKP is characterized by its arid climate with little rains in winter which reflects a unique flora and fauna diversity (Semida, 2006). SKP is one of the richest spots for flora diversity in the Middle East, from which $\sim 472$ plant species have been reported (Fayed \& Shaltout, 2004). Twenty-six endemic plant species were found in SKP which comprise 42.6\% of Egypt endemic plant species (Moustafa, Abd ElWahab, \& Shaker, 2001).

Wadi Telah is considered a long and narrow valley about $6 \mathrm{~km}$ long, with steep slopes of high boulder fields that drop to the valley bed. It is surrounded from both sides by Mt. El-Serw ( $2150 \mathrm{~m}$ high) to the east and extension of Gebel Abas Basha at the southwest (N
28.58723, E 33.92017). It has several Bedouin gardens including different types of fruit trees such as apricot, almond, apple, and date palm, so it is considered a highly diverse wadi. The dominant plants are Achillea fragrantissima, Origanum syriacum, Capparis sinaica, Peganum harmala, Asclepias sinaica, Alkanna orientalis, and Teucrium polium (Rashad, Atwa, \& El Sharqawy, 2012).

\section{Monitoring and identification of biodiversity elements in W. Telah}

A bimonthly field survey started in October 2018 to October 2019. Each monitoring session spanned over 1 week. Field monitoring of flower-visiting insects' species across the hiking trail passing through W. Telah was carried out at different distances $(\sim 0,20,40$, and $60 \mathrm{~m})$ along both sides of the hiking trail (Figs. 2 and 3). As a control, monitoring was conducted at $120 \mathrm{~m}$ from the hiking trail. Fifty sampling points that cover the different distances from the hiking trail were chosen for collecting data.

\section{Monitoring and identification of flower-visiting insects}

Monitoring of flower-visiting insects was done using transect technique, by direct observations within the study area. According to Ballantyne and Pickering (2015), several studies used observational methods to collect quantitative data, such as transect surveys and

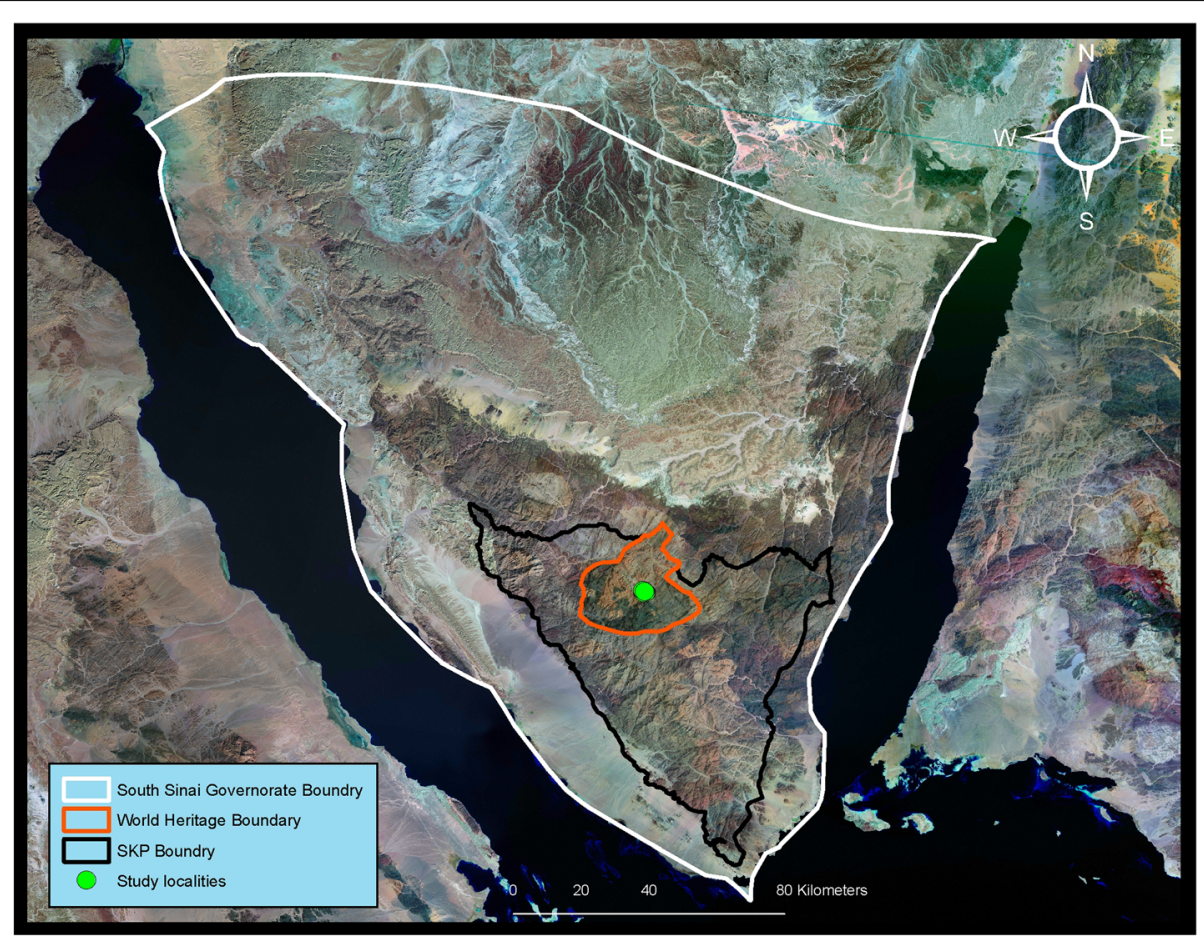

Fig. 1 Location map showing boundaries of South Sinai Governorate, World Heritage Site, and St. Katherine Protectorate. (Map source: SKP, GIS unit \& google map - https://www.google.com.eg/maps/@28.9319362,34.2174414,8z, after (Kamel, Semida, Moursy, \& Kassem, 2019)) 


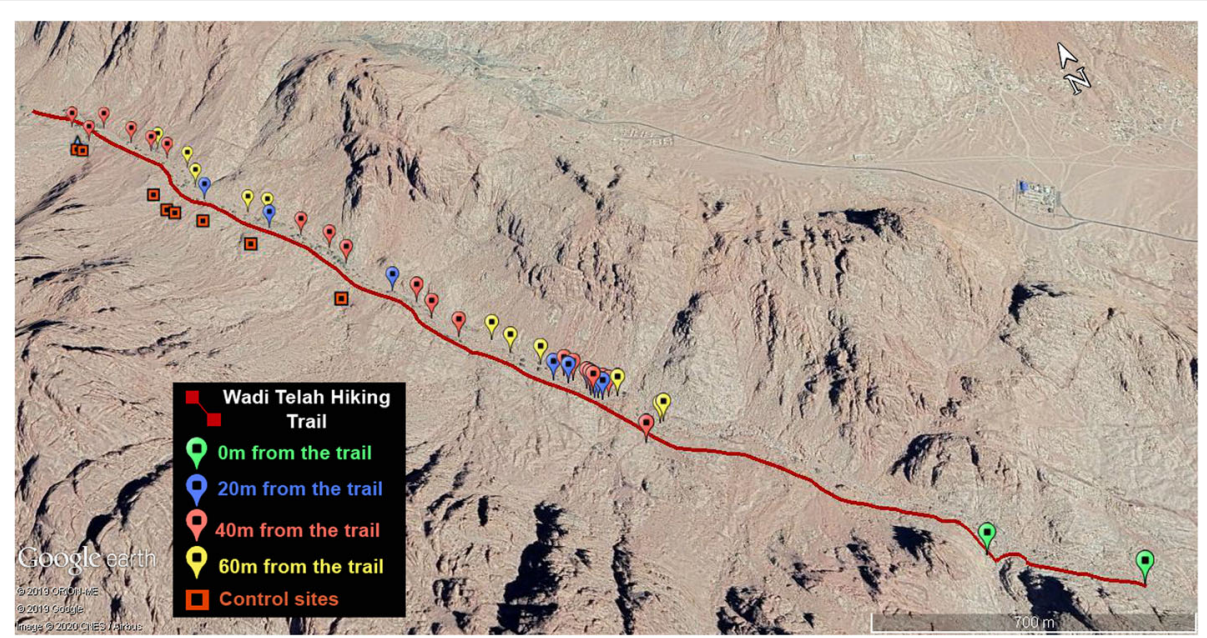

Fig. 2 Satellite map for the hiking trail passing through W. Telah (Map source: google earth https://www.google.com.eg/maps/@28.5805082,33. $9266941,1437 \mathrm{~m} /$ data $=! 3 \mathrm{~m} 1 ! 1 \mathrm{e} 3)$, in addition to fifty sampling points ( 10 points for each distance) that were chosen for collecting data

point sampling. The total number of insects' visits to the plant flowers in the 30-min focal watch and the species richness was calculated. All samples are collected using a net trap. The identification of flower-visiting insects was done by using different keys and books to reach the family level, genus level, and species level. Insects were sorted into taxa and then grouped into morpho-species based on visual characteristics. Different species of flower visitors were identified using the study of Larsen (1990), Mcgavin (1992), Goulet and Huber (1993), Gilbert and Zalat (2008), and Rashad et al. (2012).

\section{Monitoring and identification of W. Telah flora}

Floral communities in each sampling point were recorded using the quadrate technique $(5 \mathrm{~m} \times 5 \mathrm{~m})$. A flora survey sheet included the following: date, locality, point quadrates, habitat, GPS reading, altitude, plant name, and plant stage. Plant species were identified using the study of Boulos (1999, 2000, 2002, 2005), Migahid (1988), Migahid (1989), and Migahid (1990).

\section{Data analysis}

Spatial variation of flower-visiting insects' species in W. Telah was measured using species richness $(S)$ and species evenness $(E)$. Alpha diversity ( $\alpha$-diversity) within the study area was measured using Simpson's diversity index $(D)$ and the Shannon-Wiener index of diversity $(H)$. One-way ANOVA test was used to compare the distribution of the flower visitors' species richness among different distances from the hiking trail in W.

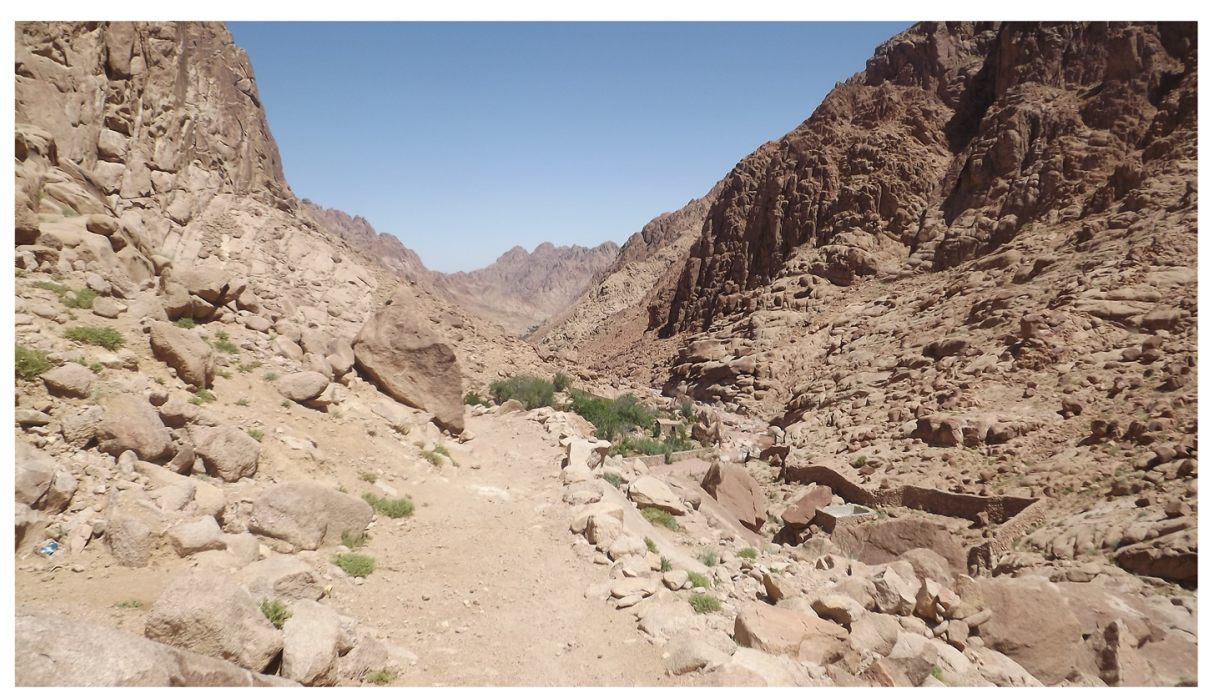

Fig. 3 A hiking trail passing through W. Telah, St. Katherine Protectorate 
Telah. Spearman correlation test was used to measure the relation between flower-visiting insects' species richness and abundance, and distance from the hiking trail for assessing the impact of the hiking trail on flower-visiting insects within W. Telah. The chi-square test of goodness-of-fit was also used to determine whether there was a significant difference in the flower visitors' diversity among different distances from the hiking trail in W. Telah. SPSS computer package (ver.18) was used to carry out the statistical analysis.

\section{Results}

Flower visitors' diversity and abundance in Wadi Telah A total of 542 individuals belonging to 34 species of flower-visitors, 16 families, from four orders were recorded from October 2018 to October 2019.

Flower-visiting insects' species recorded in the study sites of W. Telah was given in Table 1. Most species belonged to family Lycaenidae and family Pieridae from order Lepidoptera, family Dermestidae from order Coleoptera, and family Apidae from order Hymenoptera.

Table 1 Flower-visiting insects' species recorded in the study sites of W. Telah

\begin{tabular}{|c|c|c|c|}
\hline Insect order & Insect family & Flower-visiting insects' species & Number of individuals \\
\hline \multirow[t]{16}{*}{ Lepidoptera } & \multirow[t]{4}{*}{ Lycaenidae } & Deudorix livia Klug, 1834 & 2 \\
\hline & & Lampides boeticus Linnaeus, 1767 & 28 \\
\hline & & Tarucus rosaceus Austaut, 1885 & 9 \\
\hline & & Chilades trochylus Freyer, 1844 & 64 \\
\hline & Papilionidae & Papilio saharae Oberthür, 1879 & 3 \\
\hline & \multirow[t]{2}{*}{ Nymphalidae } & Danaus chrysipppus Linnaeus, 1758 & 4 \\
\hline & & Vanessa cardui Linnaeus, 1758 & 22 \\
\hline & \multirow[t]{4}{*}{ Pieridae } & Pieris rapae Linnaeus, 1758 & 11 \\
\hline & & Colias croceus Fourcroy, 1785 & 15 \\
\hline & & Colotis fausta Olivier, 1804 & 23 \\
\hline & & Pontia glauconome Klug, 1829 & 35 \\
\hline & Satyridae & Pseudotergumia pisidice Klug, 1832 & 48 \\
\hline & \multirow[t]{2}{*}{ Hesperiidae } & Carcharodus alceae Esper, 1780 & 2 \\
\hline & & Carcharodus stauderi Verity, 1925 & 7 \\
\hline & Noctuidae & Heliothis peltigera (Schiff, 1775) & 3 \\
\hline & Crambidae & Nomophila noctuella (Denis \& Schiffermuller, 1775) & 2 \\
\hline \multirow[t]{7}{*}{ Coleoptera } & Coccinellidae & Hippodamia variegata (Goeze, 1777) & 11 \\
\hline & \multirow[t]{4}{*}{ Dermestidae } & Anthrenus coloratus Reitter, 1881 & 6 \\
\hline & & Anthrenus verbasci (Linne,1767) & 12 \\
\hline & & Attagenus faciatus (Thunberg, 1795) & 5 \\
\hline & & Attagenus trifasciatus (Fabricius, 1787) & 4 \\
\hline & Curculionidae & Paramecops sinaitus (Pic, 1930) & 6 \\
\hline & Scarabaeidae & Oxythyrea cinctella Schaum, 1841 & 1 \\
\hline \multirow[t]{8}{*}{ Hymenoptera } & \multirow[t]{2}{*}{ Halictidae (bees) } & Halictus Iucidipennis Smith, 1853 & 3 \\
\hline & & Nomia sp. & 3 \\
\hline & \multirow[t]{2}{*}{ Crabronidae } & Tachysphex sp. & 1 \\
\hline & & Bembix oculata Dahlbom, 1845 & 4 \\
\hline & \multirow[t]{4}{*}{ Apidae (bees) } & Anthophora pauperata Walker, 1871 & 34 \\
\hline & & Apis mellifera Linnaeus, 1758 & 52 \\
\hline & & Melecta sp. & 2 \\
\hline & & Xylocopa sp. & 1 \\
\hline \multirow[t]{3}{*}{ Diptera } & \multirow[t]{3}{*}{ Syrphidae } & Eupeodes corollae (Fabricius, 1794) & 60 \\
\hline & & Syritta orientalis Macquart, 1842 & 42 \\
\hline & & Ischiodon aegyptius (Wiedemann, 1830) & 17 \\
\hline
\end{tabular}


However, the highest number of individuals collected belonged to family Syrphidae (order Diptera). The total diversity of flower-visiting insects in W. Telah according to Simpson's diversity index $(D)$ was $0.934 \pm 0.003$ and according to the Shannon-Wiener index of diversity $(H)$ was 2.960 with species evenness $(E)$ equal to 0.839 . The most dominant flower-visiting insects in the study area were Chilades trochylus, Eupeodes corolla, Apis mellifera, Pseudotergumia pisidice, Syritta orientalis, Pontia glauconome, and Anthophora pauperata.

No significant difference in the distribution of flower visitors' diversity among different distances from the hiking trail $(\sim 0,20,40,60$, and $120 \mathrm{~m})$ in $\mathrm{W}$. Telah was reported $\left(\chi^{2}=0.71, \mathrm{df}=4, P=0.9498\right)$ (Table 2). Although the highest species richness was recorded at distance $120 \mathrm{~m}$ from the hiking trail $(S=28)$, the highest diversity was recorded at distance $40 \mathrm{~m}$ from the hiking trail $(D=0.937 \pm 0.009$ and $H=2.907)$ due to the species evenness $(E)$ recorded at distance $40 \mathrm{~m}$ from the hiking trail $(E=0.882)$ was more than that recorded at distance $120 \mathrm{~m}$ from the hiking trail $(E=0.865)$, while lowest diversity was recorded at distance $0 \mathrm{~m}$ from the hiking trail $(D$ $=0.806 \pm 0.051$ and $H=1.311$ ) with species richness equal to four and species evenness equal to 0.946 .

\section{Spatial distribution of the flower visitors' species richness among different distances from the hiking trail in W. Telah}

There was a significant difference in the distribution of the flower visitors' species richness among different distances from the hiking trail in W. Telah $(F(4,45)=$ 11.206, $P<0.01$ ). Distance $120 \mathrm{~m}$ from the hiking trail showed the highest mean number of the flower visitors' species richness 11.5 , as compared to $3,3.3,3.5$, and 5.9 at distances $0,20,40$, and $60 \mathrm{~m}$ from the hiking trail, respectively (Fig. 4).

Post hoc test according to Tukey's method is performed to test multiple comparisons between different distances from the hiking trail in W. Telah in the distribution of the flower visitors' species richness. There was a significant difference between distances 120 and 0 ,
20,40 , and $60 \mathrm{~m}$ from the trail equal to 8.5, 8.1, 7.9, and 5.59 , respectively $(P<0.05)$.

\section{Impact of hiking trail disturbance on the flower visitors' species richness and abundance distribution within the study localities in W. Telah}

Flower visitors' species richness along the hiking trail was significantly positively correlated to the distance from the hiking trail ( $\mathrm{rs}=0.556, P<0.01$ ). The highest flower visitors' species richness at one sampling point within the study localities in W. Telah was recorded at $120 \mathrm{~m}$ from the hiking trail $(S=16)$ (Fig. 5). The abundance of flower visitors along the hiking trail was significantly positively correlated to the distance from the hiking trail ( $\mathrm{rs}=0.323, P<0.01)$. The highest flower visitors' abundance was recorded at $20 \mathrm{~m}$ from the hiking trail (10 individuals for one species) (Fig. 6).

\section{Flora diversity and abundance in Wadi Telah}

A total of 280 individuals belonging to 19 plant species and 13 families were recorded in W. Telah (Table 3), aiming at measuring the species richness, abundance, diversity, and density of plant species. Spatial variation in diversity and flora' species richness among the different distances from the trail is shown in Table 4.

The highest number of plant species belonged to family Lamiaceae. However, the highest number of individuals collected belonged to family Tetradiclidaceae. Total flora diversity in W. Telah according to Simpson's diversity index $(D)$ was $0.965 \pm 0.006$ and according to the Shannon-Wiener index of diversity $(H)$ was 2.521 with species evenness $(E)$ equal to 0.856. Peganum harmala L., Achillea fragrantissima Sch.Bip., Capparis spinosa L., Deverra tortuosa DC., Asclepias sinaica (Boiss.) Muschler., Fagonia mollis Delile., and Stachys aegyptiaca Pers. represented the most frequent species in the study localities in W. Telah.

No significant difference in the distribution of floral diversity among different distances from the hiking trail $(\sim 0,20,40,60$, and $120 \mathrm{~m})$ in W. Telah was reported $\left(\chi^{2}=0.47, \mathrm{df}=4, P=0.9764\right)$ (Table 4). According to Simpson's diversity index $(D)$, the highest diversity was

Table 2 Spatial variations in the diversity of flower-visiting insects (measured by Simpson's diversity index, Shannon-Wiener diversity index, species richness, and species evenness) among different distances from the hiking trail in W. Telah

\begin{tabular}{llllll}
\hline $\begin{array}{l}\text { Distances from } \\
\text { the hiking trail }\end{array}$ & Species richness $(\boldsymbol{S})$ & Abundance & Simpson diversity index $(\boldsymbol{D})$ & Shannon-Wiener diversity index $(\boldsymbol{H})$ & Species evenness $(\boldsymbol{E})$ \\
\hline $\mathbf{0} \mathbf{m}$ & 4 & 9 & $0.806 \pm 0.051$ & 1.311 & 0.946 \\
$\mathbf{2 0} \mathbf{~}$ & 14 & 51 & $0.915 \pm 0.016$ & 2.437 & 0.924 \\
$\mathbf{4 0} \mathbf{~}$ & 27 & 110 & $0.937 \pm 0.009$ & 2.907 & 0.882 \\
$\mathbf{6 0} \mathbf{~}$ & 21 & 116 & $0.919 \pm 0.009$ & 2.659 & 0.873 \\
$\mathbf{1 2 0} \mathbf{~}$ & 28 & 256 & $0.931 \pm 0.005$ & 2.884 & 0.865 \\
\hline
\end{tabular}




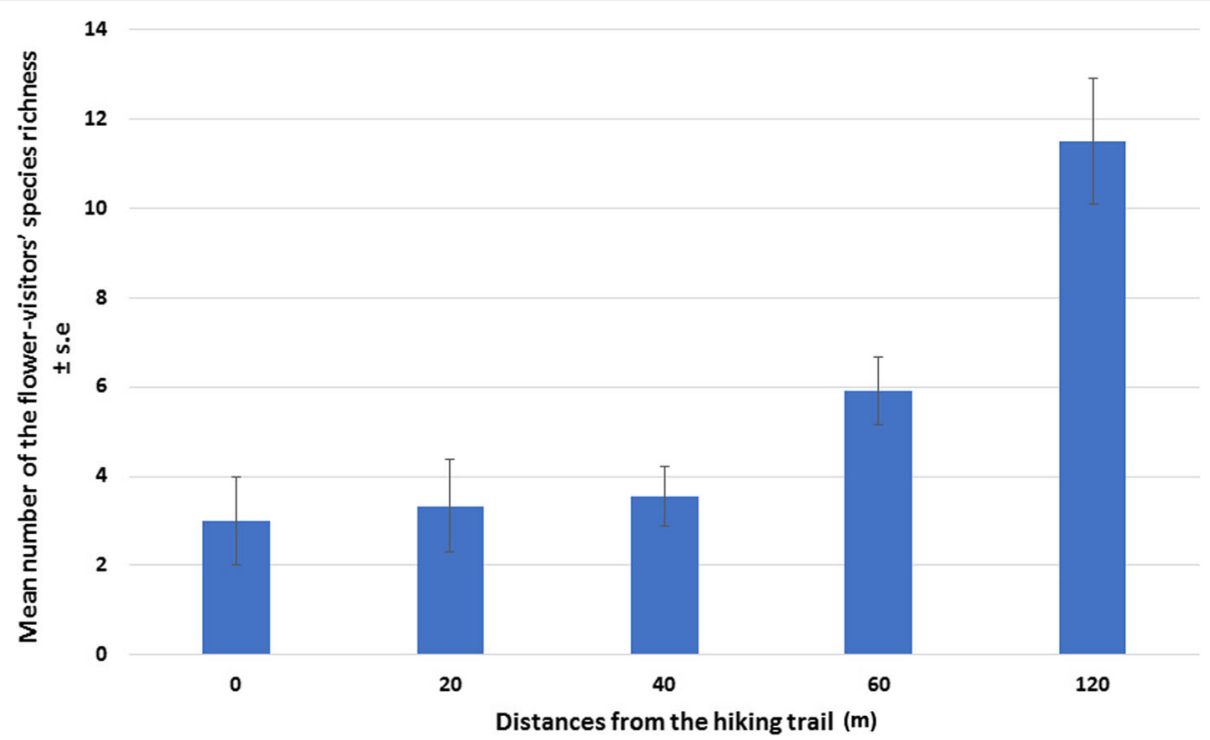

Fig. 4 The spatial pattern of the flower visitors' species richness distribution among different distances from the hiking trail in W. Telah

recorded at distance $120 \mathrm{~m}$ from the hiking trail $(D=$ $0.931 \pm 0.014)$ with species richness $(S)$ equal to 16 , while the lowest diversity was recorded at distance $20 \mathrm{~m}$ from the hiking trail $(D=0.787 \pm 0.059)$ with species richness equal to 9. According to the Shannon-Wiener diversity index $(H)$, the highest diversity was recorded at distance $40 \mathrm{~m}$ from the hiking trail $(H=2.577)$ with species evenness $(E)$ equal to 0.892 , while the lowest diversity was recorded at distance $0 \mathrm{~m}$ from the hiking trail $(H=1.475)$ with species evenness $(E)$ equal to 0.917 . The highest plant density was recorded distance $120 \mathrm{~m}$ from the hiking trail (density $=11.5$ ), while the lowest plant density was recorded distance $20 \mathrm{~m}$ from the hiking trail. The highest plant species richness was recorded at distance $40 \mathrm{~m}$ from the hiking trail.

\section{Spatial distribution of the plant species richness among different distances from the hiking trail in W. Telah}

There was a significant difference in the distribution of the plant species richness among different distances from the hiking trail in W. Telah $(F(4,45)=9.263, P<$ $0.01)$. Distance $120 \mathrm{~m}$ from the hiking trail showed the highest mean number of the plant species richness 8.5 ,

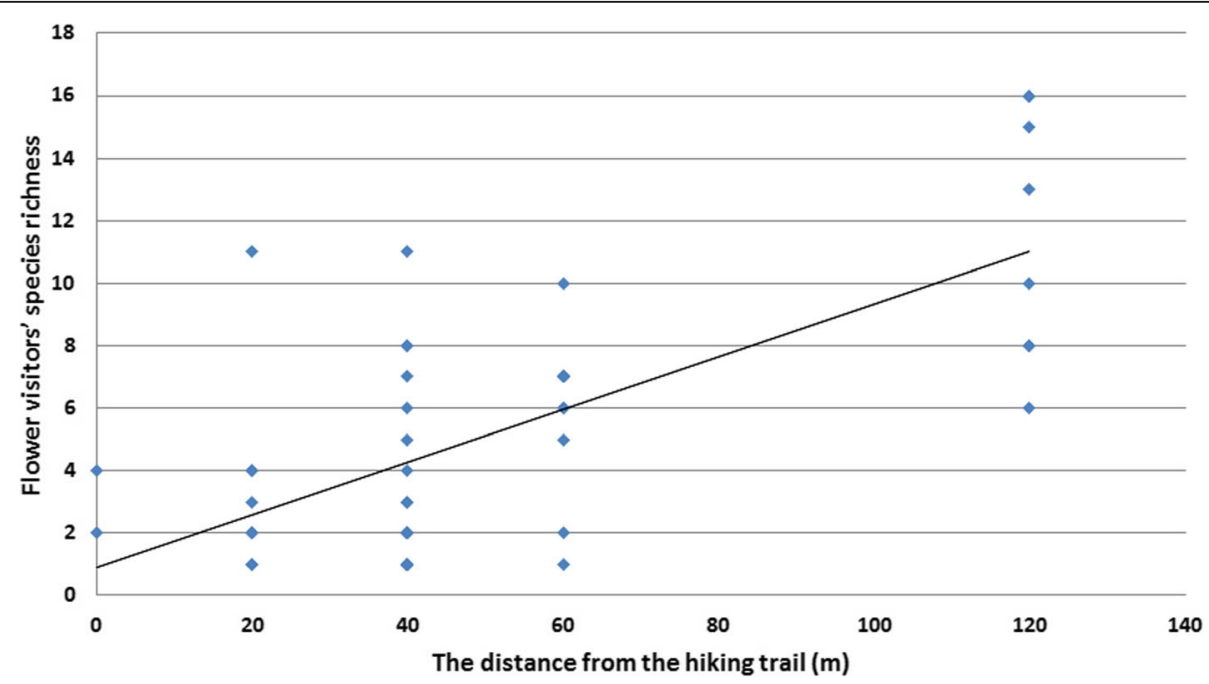

Fig. 5 The relationship between the distance from the hiking trail and flower visitors' species richness within the study localities in W. Telah 


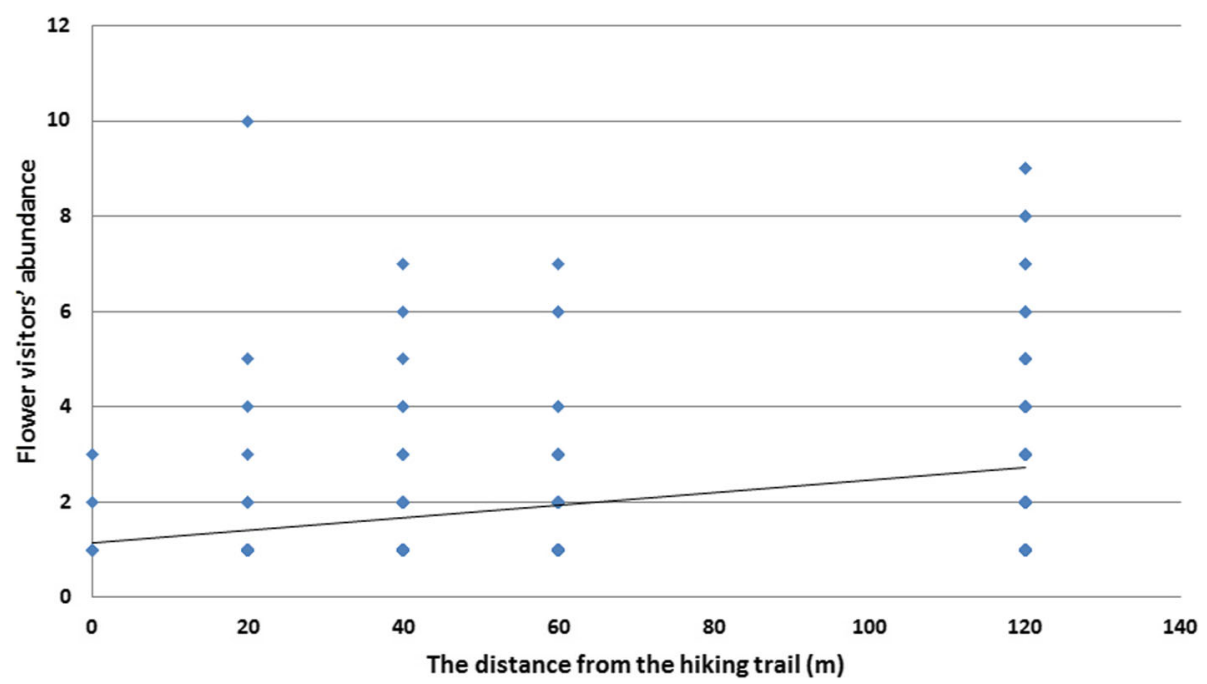

Fig. 6 The relationship between the distance from the hiking trail and flower visitors' abundance within the study localities in W. Telah

as compared to 2.5, 2.33, 3.1, and 4.7 at distances 0,20 , 40, and $60 \mathrm{~m}$ from the hiking trail, respectively (Fig. 7).

The post hoc test according to Tukey's method is performed to test multiple comparisons between different distances from the hiking trail in W. Telah in the distribution of the plant species richness. There was a significant difference between distances 120 and $0,20,40$, and $60 \mathrm{~m}$ from the trail equal to $6,6.1,5.3$, and 3.7 , respectively $(P<0.05)$.
Impact of hiking trail disturbance on the plant species richness and abundance distribution within the study localities in W. Telah

The plant species richness along the hiking trail was significantly positively correlated to the distance from the hiking trail $(\mathrm{rs}=0.563, P<0.01)$. The highest plant species richness at one sampling point within the study localities in W. Telah was recorded at $120 \mathrm{~m}$ from the hiking trail $(S=14)$ (Fig. 8$)$. The abundance of plant

Table 3 The recorded plant species within the study localities in W. Telah

\begin{tabular}{|c|c|c|}
\hline Family & Plant species & Number of individuals \\
\hline Apiaceae & Deverra tortuosa DC. & 21 \\
\hline Apocynaceae & Asclepias sinaica (Boiss.) Muschler & 19 \\
\hline \multirow[t]{3}{*}{ Asteraceae } & Achillea fragrantissima Sch.Bip. & 35 \\
\hline & Echinops glaberrimus DC. & 11 \\
\hline & Pulicaria incisa DC. & 4 \\
\hline \multirow[t]{2}{*}{ Brassicaceae } & Zilla spinosa (L.) Prantl. & 9 \\
\hline & Matthiola arabica Velen. & 3 \\
\hline Boraginaceae & Alkanna orientalis Boiss. & 7 \\
\hline Capparaceae & Capparis spinosa L. & 26 \\
\hline Fabaceae & Astragalus tribuloides Delile & 5 \\
\hline \multirow[t]{4}{*}{ Lamiaceae } & Stachys aegyptiaca Pers. & 17 \\
\hline & Teucrium polium L. & 6 \\
\hline & Origanum sinaicum (Boiss.) Greater \& Burdet. & 6 \\
\hline & Phlomis aurea Decne. & 6 \\
\hline Rosaceae & Crataegus sinaica Boiss. & 7 \\
\hline Scrophulariaceae & Verbascum sinaiticum Benth. & 6 \\
\hline Solanaceae & Hyoscyamus boveanus Asch. \& Schweinf. & 1 \\
\hline Tetradiclidaceae & Peganum harmala $\mathrm{L}$. & 70 \\
\hline Zygophyllaceae & Fagonia mollis Delile & 21 \\
\hline
\end{tabular}


Table 4 Spatial variations in the flora diversity (measured by Simpson's diversity index, Shannon-Wiener diversity index, species richness, and species evenness) and plant densities, among different distances from the hiking trail in W. Telah

\begin{tabular}{|c|c|c|c|c|c|c|}
\hline $\begin{array}{l}\text { Distances from } \\
\text { the hiking trail }\end{array}$ & $\begin{array}{l}\text { Species Richness } \\
\text { (S) }\end{array}$ & Abundance & $\begin{array}{l}\text { Simpson diversity index } \\
\text { (D) }\end{array}$ & $\begin{array}{l}\text { Shannon-Wiener diversity index } \\
(\boldsymbol{H})\end{array}$ & $\begin{array}{l}\text { Species evenness } \\
(\boldsymbol{E})\end{array}$ & Plantdensity \\
\hline $0 \mathrm{~m}$ & 5 & 7 & $0.857 \pm 0.107$ & 1.475 & 0.917 & 3.5 \\
\hline $20 \mathrm{~m}$ & 9 & 30 & $0.787 \pm 0.059$ & 1.697 & 0.772 & 3.33 \\
\hline $40 m$ & 18 & 86 & $0.921 \pm 0.020$ & 2.577 & 0.892 & 4.3 \\
\hline $60 \mathrm{~m}$ & 14 & 65 & $0.896 \pm 0.023$ & 2.338 & 0.886 & 5.9 \\
\hline $120 \mathrm{~m}$ & 16 & 92 & $0.931 \pm 0.014$ & 2.499 & 0.901 & 11.5 \\
\hline
\end{tabular}

species along the hiking trail was significantly positively correlated to the distance from the hiking trail ( $\mathrm{rs}=0$. 344, $P<0.01)$. The highest plant abundance was recorded at $40 \mathrm{~m}$ from the hiking trail (21 individuals for one species) (Fig. 9).

\section{Discussion}

One of the challenges facing conservation biology was the increase in anthropogenic effects on biodiversity hotspots (Zafra-Calvo, Rodriguez, \& Lobo, 2010). Anthropogenic activates such as land-use alteration, pathogens, pesticides, and climate change can have critical impacts on insect pollinators and the pollination services they provide (Cariveau \& Winfree, 2015). Globally, pollinators are threatened by land-use change including degradation of seminatural habitats and several studies are concerned that insect pollinators are in decline (Stein et al., 2018; Winfree et al., 2009). Hiking trails and nature-based tourism might have negative impacts on faunal biodiversity within protected areas (Huhta \&
Sulkava, 2014). Unplanned visitor-created informal trails are existed in several protected areas and perform further fragmentation effects by expanding the impact into relatively undisturbed habitats (Leung, Pickering, \& Cole, 2012). Also, recent studies have focused on the effects of anthropogenic activities such as habitat modification and fragmentation on pollinator species richness and diversity, and community composition of pollinators (Eckert et al., 2010; Stanley \& Stout, 2013; Stout, 2014).

The result showed that the diversity of flower-visiting insects in W. Telah was high. This agrees with the findings of Zalat et al. (2001) who reported that high altitude region of SKP had the highest-flying insect diversity. Also, the results reported 34 species of flower visitors are belonging to four insect orders (Coleoptera, Diptera, Hymenoptera, and Lepidoptera) in W. Telah, and 112 species are belonging to five insect orders (Coleoptera, Diptera, Hemiptera, Hymenoptera, and Lepidoptera) that were recorded before in SKP by (Norfolk \& Dathe, 2019). The present study also indicated that there were

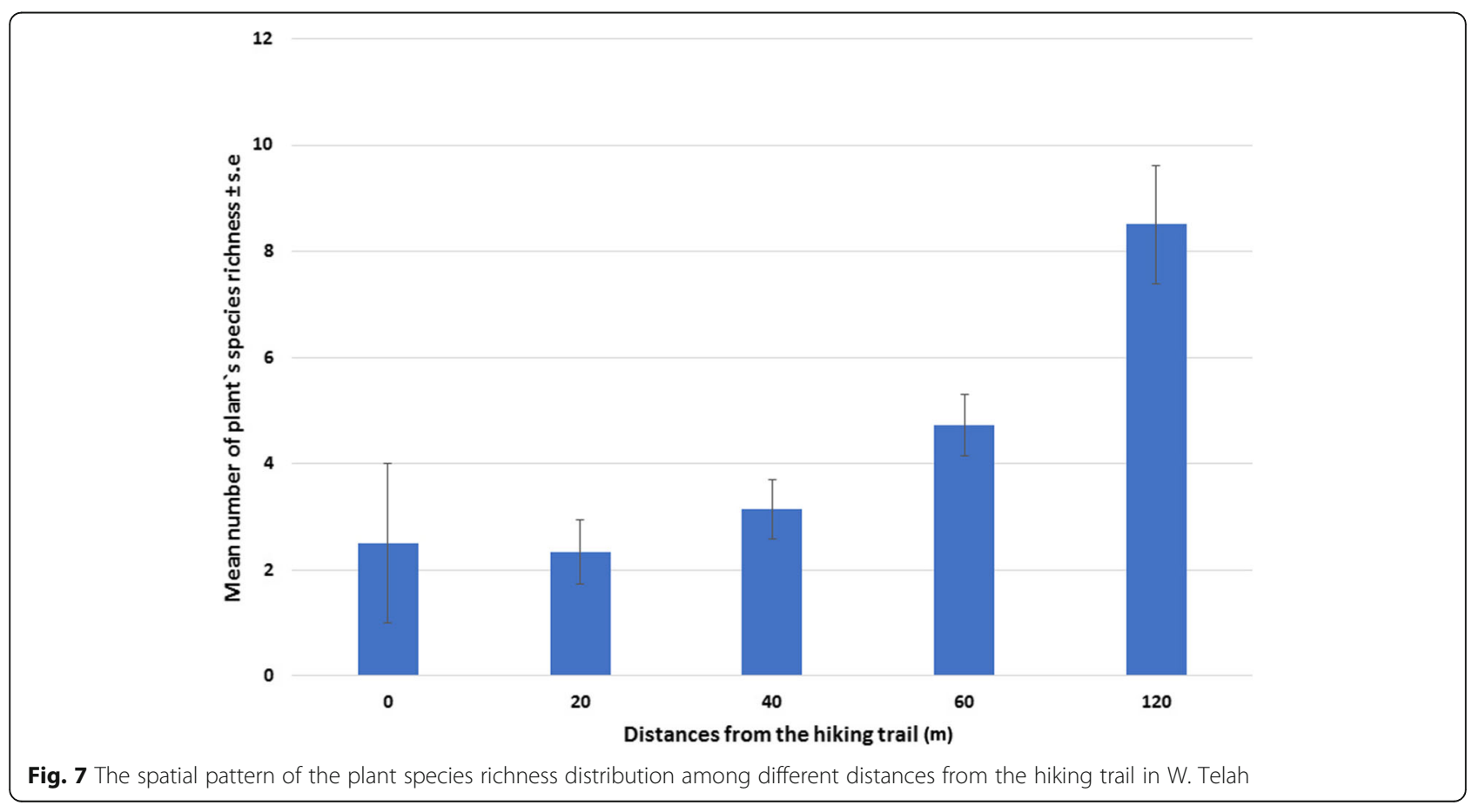




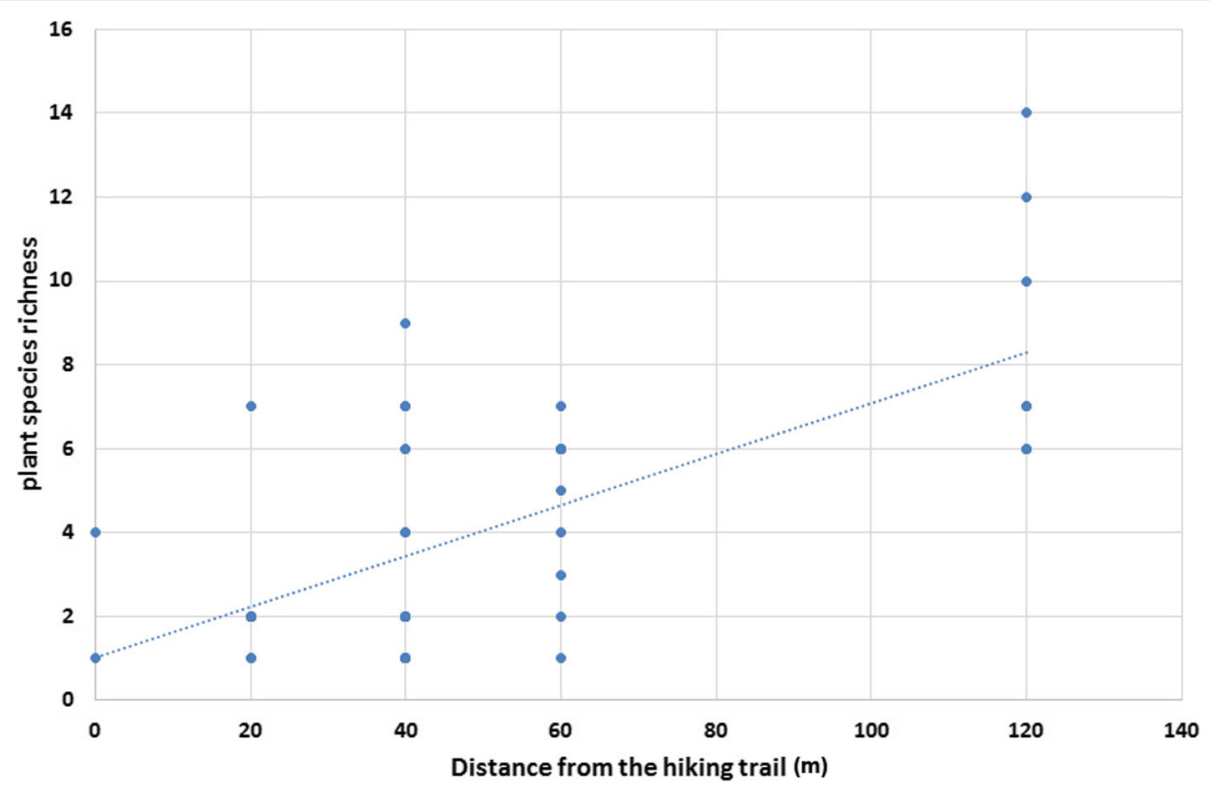

Fig. 8 The relationship between the distance from the hiking trail and the plants' species richness within the study localities in W. Telah

no significant differences in the diversity of flowervisiting insects among different distances from the trail, perhaps due to their mobility. This result is consistent with the previous study that reveals that the mobility of the flying insects among Katherine, Gebal, and Gharaba systems was the reason for not recording a significant difference in the diversity of flying insects among different systems (Zalat et al., 2001).

The present study showed that the sampling points at distance $40 \mathrm{~m}$ from the hiking trail had the highest diversity of flower visitors. This might be attributed to the high number of plant species in a flowering stage recorded mainly at that distance. This is agreeing with the previous studies showed that the provision of further floral resources increases both pollinators' diversity and abundance (Norfolk, Eichhorn, \& Gilbert, 2014b; Norfolk, Eichhorn, \& Gilbert, 2016). Also, a recent study reported that within a wadi having numerous flowers on a plant secured more insect visits (Gilbert et al., 1996). Vegetation density and species richness positively affect

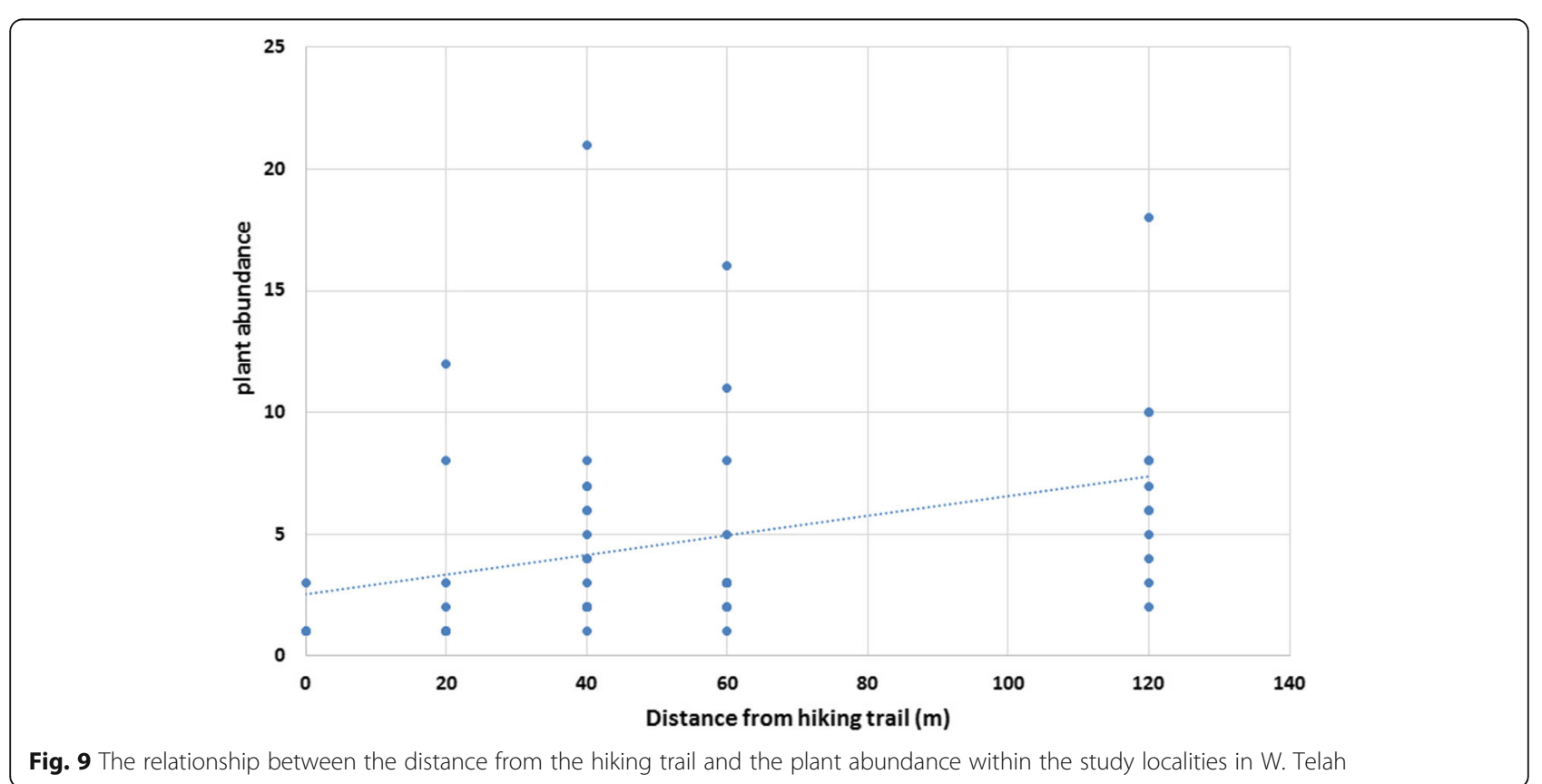


pollinator activity (Hegland \& Boeke, 2006). Floral resources can be considered as a limiting factor for populations of bees (Roulston \& Goodell, 2011), syrphid flies (Hegland \& Boeke, 2006; Meyer, Jauker, \& Steffan-Dewenter, 2009), and Lepidoptera (Ockinger \& smith, 2006).

The present study showed that the disturbance resulting from the hiking trail had a negative impact on different species of flower visitors and their associated floral resources in Wadi Telah, which is clear from the spatial distribution of species richness of flower visitors and their associated floral resources among different distances from the hiking trail in W. Telah, which is concurred with the view of Ciach, Maślanka, Krzus, and WOJAS (2017) who reported that species richness and abundance of insect pollinators decreases with increased hiking trail disturbances by a human. Similarly, Gray and Jongepier (2012) showed a decrease in insect species diversity with an increase in the human disturbance, when studying the relationship between the level of human disturbance and the diversity of arthropod communities in Kirindy Forest, Western Madagascar.

Furthermore, the results that were consistent with the previous study reveal that disturbance resulting from degradation of seminatural habitats often leads to lowered pollinator abundance and/or diversity (Stein et al., 2018). Also, butterflies and bees both exert strong negative responses to land-use change and extreme land-use causes a strong decrease in species richness and/or abundance (Winfree et al., 2009). Furthermore, habitat fragmentation and loss are the main cause of the decline in bees besides other stresses, including, exposure to parasites, pathogens and pesticides, shortage of floral sources, and the impacts of climate change (Osman \& Shebl, 2020). In contrast, the present study does not agree with recent evidence showed that moderate landuse disturbances may maximize the abundance and richness of insect pollinators, including bees (Kessler et al., 2009) and butterflies (Hogsden \& Hutchinson, 2004).

\section{Recommendation}

The investigation on how different biodiversity elements respond to hiking trails allows greater insight for protectorate managers. The study can contribute to effective management decisions for current and future protectorates. To support the conservation of biodiversity, it is advisable to encourage more researches on the impact of hiking trails and associated human activities on other biodiversity icons such as mammals, reptiles, and birds in SKP. The protectorate management units need to control the usage of informal trails and improve the conservation of plant communities in SKP.

\section{Abbreviations}

$D$ : Simpson diversity index; E: Species evenness; H: Shannon-Wiener diversity index; S: Species richness; Alt: Altitude; Fig.: Figure; GIS: Geographical
Information System.; m. a. s. I.: Meters above sea level; Mt.: Mount; P: Probability; rs: Spearman correlation coefficient; Sig.: Significant; SKP: Saint Katherine Protectorate; W: Wadi

\section{Acknowledgements}

"Not applicable"

\section{Author's information}

Name: Dr. Mohamed Kamel

Work: I am a lecturer in the Department of Environmental Basic Sciences, Institute of Environmental Studies and Research, Ain Shams University, Cairo, Egypt.

Contacts: mobile phone, 01020185448

Email: Mohamed.kamel@iesr.asu.edu.eg

\section{Author's contributions}

Dr. M. Kamel was the only author for this research; he collected, analyzed, and interpreted almost data regarding the "Impact of hiking trails on the diversity of flower-visiting insects in Wadi Telah, St. Katherine Protectorate, Egypt. He was the only contributor in writing the manuscript. The author read and approved the final manuscript".

\section{Funding}

This research did not receive any specific grant from funding agencies in the public, commercial, or not-for-profit sectors.

\section{Availability of data and materials}

The datasets used and/or analyzed during the current study are available from the corresponding author on reasonable request.

Ethics approval and consent to participate

"Not applicable"

Consent for publication

"Not applicable"

\section{Competing interests}

The author declares that he has no competing interests

Received: 12 March 2020 Accepted: 29 July 2020

Published online: 12 August 2020

\section{References}

Arenas, A., \& Farina, W. M. (2012). Learned olfactory cues affect pollen-foraging preferences in honeybees, Apis mellifera. Animal Behaviour, 83, 1023-1033.

Badawy, R. M. (2003). Two new species of the genus Anthophora Latreille from Sinai, Egypt. Bull. Ent. Soc. Egypt, 80, 1-7.

Baha El Din, S. M. 2006. A guide to the reptiles and amphibians of Egypt., American University in Cairo Press.

Barragan, F., Moreno, C. E., Escobar, F., Halffter, G., \& Navarrete, D. (2011). Negative impacts of human land use on dung beetle functional diversity. PLoS One, 6, e17976.

Biesmeijer, J. C., Roberts, S. P., Reemer, M., Ohlemuller, R., Edwards, M., Peeters, T., ... Kunin, W. E. (2006). Parallel declines in pollinators and insect-pollinated plants in Britain and the Netherlands. Science, 313, 351-354.

Boulos, L. (1999). Flora of Egypt, (vol. 1). Cairo, Egypt: Al hadara publishing.

Boulos, L. (2000). Flora of Egypt, (vol. 2). Cairo, Egypt: Al hadara publishing.

Boulos, L. (2002). Flora of Egypt, (vol. 3). Cairo, Egypt: Al hadara publishing.

Boulos, L. (2005). Flora of Egypt, (vol. 4). Cairo, Egypt: Al hadara publishing.

Cariveau, D. P., \& Winfree, R. (2015). Causes of variation in wild bee responses to anthropogenic drivers. Current Opinion in Insect Science, 10, 104-109.

Ciach, M., Maślanka, B., Krzus, A., \& WOJAS, T. (2017). Watch your step: Insect mortality on hiking trails. 10, 129-140.

Eckert, C. G., Kalisz, S., Geber, M. A., Sargent, R., Elle, E., Cheptou, P. O., ... Winn, A. A. (2010). Plant mating systems in a changing world. Trends in Ecology \& Evolution, 25, 35-43.

Fayed, A. \& Shaltout, K. 2004. Floristic Survey of the Mountainous Southern Sinai. Flora of Saint Catherine protectorate. Egypt: Conservation and sustainable use of Medicinal plants in arid and semi-arid eco-systems project (GEF, UNDP) (project no: 12347/12348), final report. 
Fouda, M., Grainger, J., Salaama, W., Baha El Din, S., Paleczny, D., Zalat, S. M., \& Gilbert, F. (2006). Management effectiveness evaluation of Egypt's protected area system. Cairo, Egypt.: Nature Conservation Sector, Egyptian Environmental Affairs Agency, Ministry of State for Environmental Affairs.

Geldmann, J., Barnes, M., Coad, L., Craigie, I. D., Hockings, M., \& Burgess, N. D. (2013). Effectiveness of terrestrial protected areas in reducing habitat loss and population declines. Biological Conservation, 161, 230-238.

Gilbert, F., Willmer, P., Semida, F., Ghazoul, J., \& Zalat, S. (1996). Spatial variation in selection in a plant-pollinator system in the wadis of Sinai, Egypt. Oecologia, 108, 479-487.

Gilbert, F., \& Zalat, S. (2008). Butterflies of Egypt. EEAA, UNDP, BioMap: Cairo.

Goulet, H., \& Huber, J. (1993). Hymenoptera of the world: An identification guide to families. Ottawa, Canada: Agriculture Canada publication.

Grainger, J. \& Gilbert, F. 2008. Cultural and spiritual values of Protected Landscapes - the St Katherine case study. . In: Mallarach, J. M. (ed.) Cultural and Spiritual Values of Protected Landscapes and Seascapes. . IUCN.

Gray, C., \& Jongepier, E. (2012). Effect of human disturbance on arthropod diversity at Kirindy Forest, Western Madagascar. Topical Biology Assessment, 8, 34-46.

Hegland, S., \& Boeke, L. (2006). Relationships between the density and diversity of floral resources and flower visitor activity in a temperate grassland community. Ecological Entomology, 31, 532-538.

Hogsden, K., \& Hutchinson, T. (2004). Butterfly assemblages along a human disturbance gradient in Ontario, Canada. Canadian Journal of Zoology-revue Canadienne De Zoologie - CAN J ZOOL, 82, 739-748.

Huhta, E., \& Sulkava, P. (2014). The impact of nature-based tourism on bird communities: A case study in Pallas-Yllastunturi National Park. Environmental Management, 53, 1005-1014

Jew, E. K. K., Loos, J., Dougill, A. J., Sallu, S. M., \& Benton, T. G. (2015). Butterfly communities in miombo woodland: Biodiversity declines with increasing woodland utilisation. Biological Conservation, 192, 436-444.

Kamel, M., Semida, F., Moursy, M. M. S., \& Kassem, H. (2019). Impact of hiking trail disturbance on ants' diversity at Mount Sinai, St. Katherine protectorate, Egypt. Journal of Environmental Science, 45, 37-56.

Kennedy, C. M., Lonsdorf, E., Neel, M. C., Williams, N. M., Ricketts, T. H., Winfree, R., Bommarco, R., Brittain, C., Burley, A. L., Cariveau, D., Carvalheiro, L. G., Chacoff, N. P., Cunningham, S. A., Danforth, B. N., Dudenhöffer, J.-H., Elle, E., Gaines, H. R., Garibaldi, L. A., Gratton, C., Holzschuh, A., Isaacs, R., Javorek, S. K., Jha, S., Klein, A. M., Krewenka, K., Mandelik, Y., Mayfield, M. M., Morandin, L., Neame, L. A., Otieno, M., Park, M., Potts, S. G., Rundlöf, M., Saez, A., Steffan-Dewenter, I. , Taki, H., Viana, B. F., Westphal, C., Wilson, J. K., Greenleaf, S. S. \& Kremen, C. 2013. A global quantitative synthesis of local and landscape effects on wild bee pollinators in agroecosystems. 16, 584-599.

Kessler, M., Stefan, A., Bos, M., Buchori, D., Putra, D., Gradstein, S., ... Tscharntke, T. (2009). Alpha and beta diversity of plants and animals along a tropical landuse gradient. Ecological applications: a publication of the Ecological Society of America, 19, 2142-2156.

Kevan, P. G. (1999). Pollinators as bioindicators of the state of the environment: Species, activity and diversity. Agriculture, Ecosystems \& Environment, 74, 373-393.

Larsen, T. 1990. The butterflies of Egypt, cairo, American University in Cairo Press.

Leung, Y.-F., Pickering, C., \& Cole, D. (2012). Informal trails and fragmentation effects: A conceptual and research overview, paper presented at the 6th international conference on monitoring and Management of Visitors in recreational and protected areas. Sweden: Stockholm.

Mader, H. J. (1984). Animal habitat isolation by roads and agricultural fields. Biological Conservation, 29, 81-96.

McGavin, G. C. (1992). The pocket to guide insects of the northern hemispere, UK London house.

Meyer, B., Jauker, F., \& Steffan-Dewenter, I. (2009). Contrasting resourcedependent responses of hoverfly richness and density to landscape structure. Basic and Applied Ecology, 10, 178-186.

Michelsen, O., McDevitt, J., \& Coelho, C. (2014). A comparison of three methods to assess land use impacts on biodiversity in a case study of forestry plantations in New Zealand. International Journal of Life Cycle Assessment, 19, 1214-1225

Migahid, A. M. (1988). Flora of Saudi Arabia, volume 1, Riyadh, Saudi Arabia, king Saud university libraries.

Migahid, A. M. (1989). Flora of Saudi Arabia, volume 2, Riyadh, Saudi Arabia, king Saud university libraries.

Migahid, A. M. (1990). Flora of Saudi Arabia, volume 3, Riyadh, Saudi Arabia, king Saud university libraries.
Moustafa, A., Abd El-Wahab, R., \& Shaker, M. (2001). Evaluation of plant diversity and endemism in Saint Catherine protectorate, South Sinai, Egypt. Egyptian Journal of Botany, 41, 121-139.

Norfolk, O. \& Dathe, H. H. 2019. Filling the Egyptian pollinator knowledge-gap: Checklist of flower-visiting insects in South Sinai, with new records for Egypt. Beiträge zur Entomologie=Contributions to Entomology, 69, 175-184.

Norfolk, O., Eichhorn, M., \& Gilbert, F. (2014a). Contrasting patterns of turnover between plants, pollinators and their interactions. Diversity and Distributions, 21

Norfolk, O., Eichhorn, M., \& Gilbert, F. (2016). Flowering ground vegetation benefits wild pollinators and fruit set of almond within arid smallholder orchards. Insect Conservation and Diversity, 9, n/a-n/a.

Norfolk, O., Eichhorn, M. P., \& Gilbert, F. (2014b). Culturally valuable minority crops provide a succession of floral resources for flower visitors in traditional orchard gardens. Biodiversity and Conservation, 23, 3199-3217.

Ockinger, E., \& smith, H. G. (2006). Landscape composition and habitat area affects butterfly species richness in semi-natural grasslands. Oecologia, 149, 526-534.

Osman, M. A. M. \& Shebl, M. A. 2020. Vulnerability of crop pollination ecosystem services to climate change. In: Ewis Omran, E.-S. \& Negm, A. M. (eds) Climate change impacts on agriculture and food security in Egypt: Land and water resources - Smart farming — Livestock, fishery, and aquaculture. Cham: Springer International Publishing.

Pęksa, Ł., \& Ciach, M. (2018). Daytime activity budget of an alpine ungulate (Tatra chamois Rupicapra rupicapra tatrica): Influence of herd size, sex, weather and human disturbance. Mammal Research, 63, 443-453.

Pickering, C. M., \& Hill, W. (2007). Impacts of recreation and tourism on plant biodiversity and vegetation in protected areas in Australia. Journal of Environmental Management, 85, 791-800.

Queiroz, R., Ventura, M., \& Silva, L. (2014). Plant diversity in hiking trails crossing Natura 2000 areas in the Azores: Implications for tourism and nature conservation. Biodiversity and Conservation, 23.

Rashad, S., Atwa, W., \& El Sharqawy, A. (2012). Insects on medicinal plants in Saint Katherine protectorate, ecological and biological studies on insects associated with medicinal plants in Saint Katherine protectorate, Egypt. Germany: Lambert Academic Publishing $\mathrm{GmbH} \& \mathrm{Co}$.

Reilly, M. L., Tobler, M. W., Sonderegger, D. L., \& Beier, P. (2017). Spatial and temporal response of wildlife to recreational activities in the San Francisco Bay ecoregion. Biological Conservation, 207, 117-126.

Roulston, T. H., \& Goodell, K. (2011). The role of resources and risks in regulating wild bee populations. Annual Review of Entomology, 56, 293-312.

Semida, F. (2000). Nesting behaviour of Anthophora pauperata (hymenoptera: Anthophoridae) in the St Katherine ecosystem. Sinai., 2.

Semida, F. M. M. (2006). Ungulate grazing impact on the local distribution of the rare species Rhopalomyia Tanaceticola karsh. (Diptera: Cecidomyiidae), in South Sinai ecosystem. Bulletin of the Entomological Society of Egypt, 83, 51-60

Shakeel, M., Ali, H., Ahmad, S., Said, F., Khan, K. A., Bashir, M. A., ... Ali, H. (2019). Insect pollinators diversity and abundance in Eruca sativa mill. (arugula) and Brassica rapa L. (field mustard) crops. Saudi Journal of Biological Sciences, 26, 1704-1709.

Shebl, M., \& Farag, M. M. (2015). Bee diversity (hymenoptera: Apoidea) visiting broad bean (Vicia faba L.) flowers in Egypt. Zoology in the Middle East, 61(3), 256-263.

Shebl, M., Kamel, S., \& Mahfouz, H. (2013). Bee fauna (Apoidea: Hymenoptera) of the Suez Canal region, Egypt. Journal of Apicultural Science, 57, 33-44.

Shebl, M., Patiny, S., \& Michez, D. (2015). Supplementary note on the solitary bee fauna from the Suez Canal region of Egypt (hymenoptera: Apoidea). Journal of Melittology, 47, 1-5.

Siddig, A. A. H., Ellison, A. M., Ochs, A., Villar-Leeman, C. \& Lau, M. K. 2016. How do ecologists select and use indicator species to monitor ecological change? Insights from 14 years of publication in ecological indicators. Ecological Indicators, 60, 223-230.

Sinclair, A. R., Mduma, S. A., \& Arcese, P. (2002). Protected areas as biodiversity benchmarks for human impact: Agriculture and the Serengeti avifauna. Proceedings of the Biological Sciences, 269, 2401-2405.

Siregar, E. H., Atmowidi, T., \& Kahono, S. (2016). Diversity and abundance of insect pollinators in different agricultural lands in Jambi, Sumatera. HAYATI Journal of Biosciences, 23, 13-17.

SKP-M.P 2003. Saint Katherine protectorate management plan. . Reference edition ed. EGYPT: nature conservation sector-EEAA. 
Souza, A. C. D., \& Prevedello, J. A. (2020). The importance of protected areas for overexploited plants: Evidence from a biodiversity hotspot. Biological Conservation, 243, 108482.

Stanley, D., \& Stout, J. (2013). Quantifying the impacts of bioenergy crops on pollinating insect abundance and diversity: A field-scale evaluation reveals taxon-specific responses. Journal of Applied Ecology, 50, 335-344.

Stein, K., Stenchly, K., Coulibaly, D., Pauly, A., Dimobe, K., Steffan-Dewenter, I., ... Linsenmair, K. E. (2018). Impact of human disturbance on bee pollinator communities in savanna and agricultural sites in Burkina Faso, West Africa. Ecology and Evolution, 8, 6827-6838.

Stout, J. C. (2014). Anthropogenic impacts on pollination networks and plant mating systems. 28, 1-2

Tomczyk, A. M. (2011). A GIS assessment and modelling of environmental sensitivity of recreational trails: The case of Gorce National Park, Poland. Applied Geography, 31, 339-351.

Winfree, R., Aguilar, R., Vázquez, D. P., Lebuhn, G., \& Aizen, M. A. (2009). A metaanalysis of bees' responses to anthropogenic disturbance. 90, 2068-2076.

Winfree, R., Bartomeus, I., \& Cariveau, D. P. (2011). Native pollinators in anthropogenic habitats. Annual Review of Ecology, Evolution, and Systematics, $42,1-22$

Zafra-Calvo, N., Rodriguez, M., \& Lobo, J. (2010). Discerning the impact of humanmediated factors on biodiversity using bioclimatic envelope models and partial regression techniques. Diversity and Distributions, 16, 300-309.

Zalat, S., Semida, F., Banna, S., Hassaneen, E., El Alqamy, H., Behnke, J., James, M. \& Gilbert, F. 2001. Spatial variation in the biodiversity of Bedouin gardens in the St Katherine Protectorate. Egyptian Journal of Biology, 3(2), 147-155.

\section{Publisher's Note}

Springer Nature remains neutral with regard to jurisdictional claims in published maps and institutional affiliations.

\section{Submit your manuscript to a SpringerOpen ${ }^{\circ}$ journal and benefit from:}

- Convenient online submission

- Rigorous peer review

- Open access: articles freely available online

- High visibility within the field

- Retaining the copyright to your article

Submit your next manuscript at $\boldsymbol{\nabla}$ springeropen.com 